\title{
PROLONGING THE MARKETING PERIOD OF ROSE PLANTS THROUGH WAXING AND COLD STORAGE El-Shoura, H.A.S ${ }^{1}$ and Amal A. Zaki ${ }^{2}$ \\ ${ }^{1}$ Dept. of Horticulture, Faculty of agric., Ain Shams Uni. Cairo, Egypt \\ ${ }^{2}$ Horticulture Research Institute, Agric., Research center, Giza, Egypt
}

\begin{abstract}
Roses (Rosa hybrida, cv. Eiffel Tower) grafted onto $R$. canina were lifted on $1^{\text {st }}$ Feb. 2006 and 2007. The bare - rooted one year old roses were treated with hot paraffin wax or polyethylene emulsion, packaged with polyethylene pags and later with cardbord poxes and placed in cold storage at $0^{\circ} \mathrm{C}$, RH95\%. After 4, 8, 12 or 16 weeks in cold storage the bare - rooted roses were planted in pots containing clay +sand 2:1 under saran house. Plants were tested for water loss, survival plants, and numbers of buds, number of flowers and stem length. Also carbohydrates concentration were measured in rose plants in the different storage periods. Paraffin wax treated plants lost the minimum amount of water than polyethylene emulsion and control plants in all cold storage periods respectively. Also, $100 \%$ of paraffin wax treated plants developed till flowering in all cold storage periods, while $45.8 \%$ of polyethylene emulsion treated plans and $58.9 \%$ of control plants were developed only during the two seasons. The biggest number of buds, and flowers and stem length were significantly recorded in paraffin wax treated plants than control and polyethylene emulsion treated plants respectively.

There were slight differences between all treatments concerning carbohydrates concentrations as well as in different storage periods.
\end{abstract}

\section{INTRODUCTION}

Roses are considered as the most important cut flower crop in Egypt and in the world. Rose plants are used for the purposes of cut-flowers, home gardens and landscape. Handling bare-root rose plants in Egypt is only in the coldest month in winter like deciduous plants. The object of this experiment was to use surface coating materials such as hot paraffin wax or polyethylene emulsion and cold storage to decrease respiration and water loss content of stored rose plants to extend the period of handling for several months instead of only one month in the year and in addition, increasing rose plans for export.

\section{MATERIALS AND METHODS}

This study was carried out at Post-Harvest Department, Horticulture Research Institute, Giza, Egypt, for two successive years (2006-2007). One year old uniform "Eiffel Tower" rose plants grafted on Rosa canina were lifted on $1^{\text {st }}$ Feb. 2006 and 2007. The plants washed to remove all soil debris from canes and roots. Then plants were cut to $30 \mathrm{~cm}$ long above the grafting union. Rose plant canes were dipped in melted paraffin wax $\left(85^{\circ} \mathrm{C}\right)$ for 3 seconds. The second treatment was spraying canes of rose plants with 
watery emulsion (polyethylene, wax \& resin $8 \% \mathrm{~W} / \mathrm{V}$ ) for 2 seconds. Control plants received no further treatment.

Every treat plants were placed in polyethylene bag and placed inside cardboard box and put in cold storage at $0^{\circ} \mathrm{C}$ and relative humidity $95 \%$ for 4 , 8,12 and 16 weeks. After the end of cold storage periods rose plants were planted in $20 \mathrm{~cm}$, diameter plastic pots filled with 2:1 clay and sand. (V;V) and put in saran house for two months. A completely randomized block design was used and every treatment was replicated three times and each replicate contained 6 rose plants. The differences between treatments were determined by using LSD test according to Snedecor and Cochran 1980.

The following data were recorded:

- Weight loss during storage periods (percentages)

- $\quad$ Survival plants after planting (percentages)

- Number of buds, and flowers and stem length for two months after planting.

- The determination of carbohydrates in whole rose plants during cold storage period was done according to the method mentioned by Shaffer and Hartman, (1921).

\section{RESULTS}

\section{Weight loss of rose plants (\%) :}

The results of the effect of cold storage periods, paraffin wax and polyethylene emulsion on the weight loss of "Eiffel Tower" rose plants in the two seasons are presented in Table (1) and Fig. (1). The results indicated that the longer the plants remained in cold storage the more loss of plant weight for the all treatments in different cold storage period in the two seasons.

Also paraffin wax treatment gave significantly the lowest loss of weight compared with polyethylene emulsion and control respectively in the two seasons.

Table (1): Effect of cold storage periods, paraffin wax and polyethylene emulsion on weight loss (\%) of bare rooted of Eiffel tower rose plants in the two seasons of $2006-2007$.

\begin{tabular}{|c|c|c|c|c|c|c|c|c|}
\hline \multirow{3}{*}{ Treatments } & \multicolumn{8}{|c|}{ Storage periods } \\
\hline & \multicolumn{4}{|c|}{ First season } & \multicolumn{4}{|c|}{ Second season } \\
\hline & $\begin{array}{c}4 \\
\text { weeks }\end{array}$ & $\begin{array}{c}8 \\
\text { weeks }\end{array}$ & $\begin{array}{c}12 \\
\text { weeks }\end{array}$ & $\begin{array}{c}16 \\
\text { weeks }\end{array}$ & $\begin{array}{c}4 \\
\text { weeks }\end{array}$ & $\begin{array}{c}8 \\
\text { weeks }\end{array}$ & $\begin{array}{c}12 \\
\text { weeks }\end{array}$ & $\begin{array}{c}16 \\
\text { weeks }\end{array}$ \\
\hline Control & 1.80 & 2.10 & 2.43 & 2.78 & 1.60 & 2.02 & 2.58 & 3.09 \\
\hline Paraffin wax & 1.02 & 1.04 & 1.08 & 1.11 & 0.96 & 1.11 & 1.23 & 1.42 \\
\hline $\begin{array}{l}\text { Polyethylene } \\
\text { emulsion }\end{array}$ & 1.50 & 1.85 & 2.21 & 2.50 & 1.42 & 1.72 & 2.15 & 2.40 \\
\hline LSD 5\% & 0.12 & 0.12 & 0.71 & 0.16 & 0.07 & 0.07 & 0.07 & 0.14 \\
\hline
\end{tabular}


J. Agric. Sci. Mansoura Univ., 33 (5), May, 2008

$\mathrm{F} 1$

3611 


\section{Survival plants (\%)}

The results of the effect of cold storage periods, paraffin wax and polyethylene emulsion on the survival plants of 'Eiffel Tower' rose plants in

the two seasons are presented in Table (2) and Fig. (2). The results showed that after 4 weeks of cold storage paraffin wax and control treatments gave significantly the higher rate of survival plants $(100 \%)$ than polyethylene emulsion treatment $(76.73$ and $74.46 \%)$ in the first and second season respectively.

While after 8 weeks of cold storage paraffin wax and control treatments gave also significantly the higher rate of survival plants (100 and $77.73 \%$ ) than polyethylene emulsion treatment $(62.63 \%)$ in the two seasons.

After 12 weeks of cold storage the same pattern was noticed. After 16 weeks of cold storage the results showed the superior significant effect of paraffin wax treatment with (100\%) over control and polyethylene emulsion with $(00.0 \%)$ in the two seasons.

\section{Number of buds}

After planting 'Eiffel Tower' rose plants which achieved different cold storage periods the number of swollen buds on canes were recorded. Data presented in Table (3) showed that after 4 weeks of cold storage paraffin wax treatment gave significantly the biggest number of buds $(3.7,4.2)$ than polyethylene emulsion $(3.2,3.4)$ and control $(3.25,357)$ in the first and second seasons respectively.

The same trend was observed after 8 and 12 weeks of cold storage in the two seasons. After 16 weeks of cold storage paraffin wax gave significantly the biggest number of buds $(6.4,6.87)$ than the other treatments (0.0)

Table (2): Effect of cold storage periods, paraffin wax and polyethylene emulsion on survival plants (\%) of bare - rooted of Eiffel Tower rose plants in the two seasons of $2006-2007$.

\begin{tabular}{|c|c|c|c|c|c|c|c|c|}
\hline \multirow{3}{*}{ Treatments } & \multicolumn{8}{|c|}{ Storage periods } \\
\hline & \multicolumn{4}{|c|}{ First season } & \multicolumn{4}{|c|}{ Second season } \\
\hline & $\begin{array}{c}4 \\
\text { weeks }\end{array}$ & $\begin{array}{c}8 \\
\text { weeks }\end{array}$ & $\begin{array}{c}12 \\
\text { weeks }\end{array}$ & $\begin{array}{c}16 \\
\text { weeks }\end{array}$ & $\begin{array}{c}4 \\
\text { weeks }\end{array}$ & $\begin{array}{c}8 \\
\text { weeks }\end{array}$ & $\begin{array}{c}12 \\
\text { weeks }\end{array}$ & $\begin{array}{c}16 \\
\text { weeks }\end{array}$ \\
\hline Control & 100.0 & 80.73 & 60.80 & 0.0 & 100.0 & 74.73 & 55.46 & 0.0 \\
\hline Paraffin wax & 100.0 & 100.0 & 100.0 & 100.0 & 100.0 & 100.0 & 100.0 & 100.0 \\
\hline $\begin{array}{l}\text { Polyethylene } \\
\text { emulsion }\end{array}$ & 76.73 & 60.80 & 40.46 & 0.0 & 74.46 & 64.46 & 49.80 & 0.0 \\
\hline LSD 5\% & 0.39 & 0.41 & 0.45 & 0.07 & 1.09 & 1.09 & 0.98 & 0.07 \\
\hline
\end{tabular}

\section{Stem length $(\mathrm{cm})$}

Data presented in table (3) showed that after 4 weeks of cold storage paraffin wax treatment gave significantly the tallest stem length $(23.50,24.73)$ than control $(21.23,18.57)$ and polyethylene emulsion $(20.87,17.9)$ in the two seasons respectively. 
J. Agric. Sci. Mansoura Univ., 33 (5), May, 2008

F2 
The same trend was observed after 8 weeks of cold storage in the two seasons. After 12 and 16 weeks of cold storage paraffin wax treatment gave significantly the tallest stems than polyethylene emulsion and control in the two seasons.

Number of flowers/plant :

concerning that paraffin wax treatment Table(3) a significant biggest number of flowers in all different cold storage period was noticed than control and polyethylene emulsion treatments in the two seasons.

It may be added that the number of flowers decreased with the increase of cold storage duration in all treatments. It may be due to the dryness of buds.

Carbohydrates concentration in stored rose plants:

Total carbohydrates concentration were measured in whole plant in the different storage periods.

Data presented in table (4) showed that there were very little differences between treatments when different storage periods were compared with each other.

Also, storage periods affected slightly the concentration of carbohydrates in rose plants, in increase or decrease rate.

Table (3): Effect of cold storage periods, paraffin wax and polyethylene emulsion on number of buds, stem length and number of flowers of bare-rooted of Eiffel Tower rose plants in the two seasons of 2006-2007.

\begin{tabular}{|c|c|c|c|c|c|c|c|c|c|c|c|c|}
\hline \multirow{3}{*}{ Treatments } & \multicolumn{12}{|c|}{ First Season } \\
\hline & \multicolumn{3}{|c|}{4 weeks } & \multicolumn{3}{|c|}{8 weeks } & \multicolumn{3}{|c|}{12 weeks } & \multicolumn{3}{|c|}{16 weeks } \\
\hline & N.buds & S.length & N.Flowers & N.buds & S.length & N.Flowers & N.buds & S.length & N.flowers & N.buds & S.length & N.Flower \\
\hline Control & 3.25 & 21.23 & 0.42 & 5.2 & 20.83 & 0.40 & 5.10 & 14.33 & 0.42 & \begin{tabular}{|l|}
0.0 \\
\end{tabular} & 0.0 & 0.0 \\
\hline Paraffin wax & 3.7 & 23.50 & 0.64 & 5.4 & 26.4 & 0.60 & 5.7 & 21.99 & 0.68 & 6.4 & 15.03 & 0.35 \\
\hline \begin{tabular}{|l|} 
Plyethylene \\
emulsion
\end{tabular} & 3.2 & 20.87 & 0.42 & 3.6 & 18.00 & 0.31 & 4.1 & 16.10 & 0.15 & 0.0 & 0.0 & 0.0 \\
\hline \multirow[t]{2}{*}{ LSD 5\% } & 0.20 & 0.97 & 0.07 & 0.29 & 0.78 & 0.12 & 0.37 & 0.23 & 0.51 & 0.12 & 0.32 & 0.07 \\
\hline & \multicolumn{12}{|c|}{ Second Season } \\
\hline \multirow{2}{*}{ Treatments } & \multicolumn{3}{|c|}{4 weeks } & \multicolumn{3}{|c|}{8 weeks } & \multicolumn{3}{|c|}{\begin{tabular}{|c|}
12 weeks \\
\end{tabular}} & \multicolumn{3}{|c|}{16 weeks } \\
\hline & N.buds & S.length & N.Flowers & N.buds & S.length & N.Flowers & N.buds & S.length & N.flowers & N.buds & S.length & N.flower \\
\hline Control & 3.57 & 18.57 & 0.35 & 4.06 & \begin{tabular}{|l|}
17.20 \\
\end{tabular} & 0.38 & 4.8 & 15.43 & 0.21 & \begin{tabular}{|l|}
0.0 \\
\end{tabular} & 0.0 & 0.0 \\
\hline $\begin{array}{l}\text { Parrafin } \\
\text { wax }\end{array}$ & 4.2 & 24.73 & 0.61 & 5.17 & 23.10 & 0.53 & 5.8 & 21.4 & 0.36 & 6.87 & 28.9 & 0.4 \\
\hline $\begin{array}{l}\text { Polyethylene } \\
\text { emulsion }\end{array}$ & 3.4 & 17.9 & 0.47 & 3.06 & 16.13 & 0.34 & 3.3 & 15.6 & 0.12 & 0.0 & 0.0 & 0.0 \\
\hline LSD 5\% & 0.07 & 0.7 & 0.04 & 0.35 & 0.05 & 0.07 & 0.25 & 0.37 & 0.07 & 0.78 & 2.75 & 0.07 \\
\hline
\end{tabular}

\section{DISCUSSION}

\section{Waxing and surface coatings :}

The application of wax or wax emulsion coating to certain perishable products has been practiced for many years. Waxing reduces moisture loss and, thus, retard shriveling (Platenius, 1939) and (Segall, et al 1974). Some types of nursery stock keep better in storage and during marketing after receiving a wax coating. Dormant rose plants are an example (Miller, et al 
1950). Toy, et al 1961). Application methods include spraying with or dipping into water emulsions. Roses are more to desiccation compared to other woody nursery stock (Toy and Mahlstede, 1959). Lyle (1955) confirmed that hot wax treatment was not detrimental to vegetative and reproductive growth when rose canes were exposed from 1 to $6 \mathrm{sec}$. to wax between 77 and $98^{\circ} \mathrm{C}$.

\section{Weight loss of rose plants :}

Welch and Cameron (1990) suggested that hot wax treatment is more effective in preventing moisture loss from the plants during storage and display than other treatments studied. Higher moisture content of rose canes may result in more rapid recovery and more vigorous vegetative growth once plants are removed from cold storage.

Cameron and Maqbool (1986) pointed out that, water loss varied from nearly $0 \%$ to $60 \%$ based on the difference between initial and final fresh weights.

\section{Number of buds:}

A similar increase in the number of lateral breaks was observed for the waxed roses compared to nontreated ones after transplanting (Welch and Cameron, 1990).

\section{Carbohydrates concentration:}

Menoud, et al (1991) indicated that during the first eight weeks of storage at $1^{\circ} \mathrm{C}$ of 'Mme A.Meillanel' rose plants soluble carbohydrates concentration in shoots, bottom breaks and graft union remained constant, while those in the tap-root and lateral roots increased.

Similar results have been reported in Malus doemstica during winter (Kandiah, 1979) and in lilium longiflorum bulbs stored at $-1^{\circ} \mathrm{C}$ (Miller and Longhans, 1990). During the following 8 weeks of cold storage, glucose and fructose accumulated in the hole plant, except in the shoots, while sucrose concentration decreased and starch hydrolysis ceased.

After 16 weeks period in cold storage, the total changes were slightly which is indicative to low respiration rtes. So, the results suggest that the establishment and subsequent growth of cold stored plants do not depend on the total amount of carbohydrates accumulated before lifting.

Table (4) : Effect of cold storage periods, paraffin wax and polyethylene emulsion on total carbohydrates (g glucose/100 gm D.M) in bare-rooted of Eiffel Tower rose plants in the two seasons of 2006-2007.

\begin{tabular}{|l|c|c|c|c|}
\hline \multirow{2}{*}{ Treatments } & \multicolumn{4}{|c|}{ First season } \\
\cline { 2 - 5 } & 4 weeks & $\mathbf{8}$ weeks & $\mathbf{1 2}$ weeks & $\mathbf{1 6}$ weeks \\
\hline Control & 13.06 & 13.36 & 12.60 & 13.00 \\
Paraffin & 14.20 & 13.90 & 13.87 & 12.96 \\
Polyethylene & 13.90 & 12.96 & 13.20 & 13.10 \\
\hline Treatments & \multicolumn{4}{|c|}{ Second season } \\
\cline { 2 - 5 } & $\mathbf{4}$ weeks & $\mathbf{8}$ weeks & $\mathbf{1 2}$ weeks & $\mathbf{1 6}$ weeks \\
\hline Control & 15.12 & 15.40 & 15.90 & 14.80 \\
Paraffin & 15.80 & 14.45 & 14.85 & 14.10 \\
Polyethylene & 14.90 & 13.95 & 14.20 & 13.90 \\
\hline
\end{tabular}




\section{REFERENCES}

Cameron, A.C. and M., Maqbool (1986). Postharvest storage of bare-root hardy perennials. The relation of water loss in storage survival. Acta. Hort. 181, 323-330.

Kandiah, S., 1979. Turnover of carbohydrates in relation to growth of apple trees - II distribution of ${ }^{14} \mathrm{C}$ assimilates labeled in aulmn, spring and summer. Ann. Bot. 44: 185-195.

Lyle, F.W. 1955. Hot waxing of rose bushes for store trade. Amer. Rose Ann. 40: 113-115.

Menoud, M.A.; Mauget, J.C.; Frossard, J.S. (1991). Effect of cold storage duration on budbreak, root regeneration and carbohydrate content of 'Mme A. Meilland' rose plants. Acta Horticulture 17: 237-245.

Miller, E.J., V.R. Gardner, H.G. Petering and Others. 1950. Studies on the development, preparation, properties and application of wax emulsions for coating nursery stock and other plant materials. Mich. Agr. Expt. Sta. Tech. Bul. 218, 78p.

Miller, W.B. and Langhans, R.W., 1990. Low temperature alters carbohydrate metabolism in eastern Lily bulbs. Hort Science 25: 463-465.

Platenius, H. 1939. Effect of temperature on the rate of deterioration of fresh vegetables. Jour. Agr. Res. 59: 41-58.

Segall, R.H., A. Dow, and P.L. Davis. 1974. Effect of waxing on decay, weight loss and volatile pattern of cucumbers. Proc. Fla. State Hort. Sci. 87: 250-251.

Shaffer, P.A. and Hartman, A.F. (1921). The idometric determination of cupper and its use in sugar analysis. (Modified by Noakell E.J. and ElGawadi, A, Barnell: New Phytol, 35: 225-266. Jour. Biol. Chem. 45: 365.

Snedecor, G.W. and W.G. Cochran 1980. Statistical Methods. $7^{\text {th }}$ Edition, lowa State Univ., Press, Ames.

Toy, S.J. and J.P. Mahlstede, 1959. Responses of rose plans to cane coating with melted paraffin wax. lowa State College J. Sci. 33 (4): 475-488.

Toy, S.J., J.P. Mahlstede, and F.G. Smith. 1961. Some effects of coating the canes of dormant rose plants with melted paraffin waxes. Proc. Amer. Soc. Hort. Sci. 77; 583-586.

Welch, C.K. and A.C. Cameron 1990. Elevated temperatures during simulated marketing reduces field performance of packaged rose bushes. Hort. Science 25: 677-679.

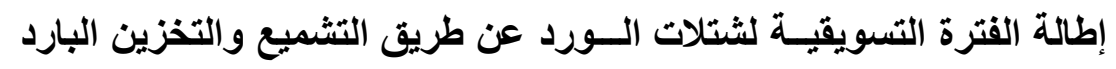




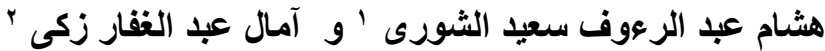

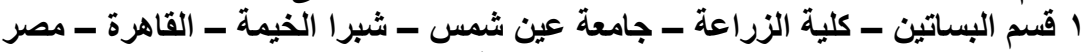

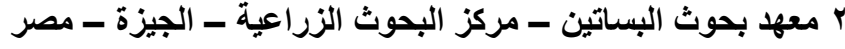

تم تقليع نباتات هجين الورد صنف برج إيفل ـ إئل عمر سنة و المطعوم على أصل ورد النسر

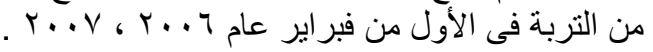

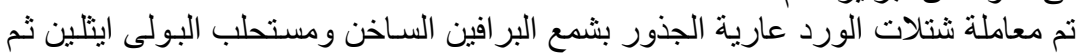

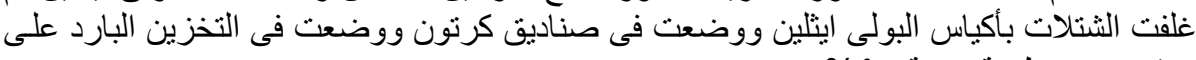

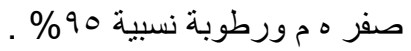

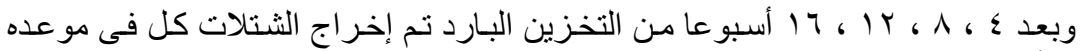

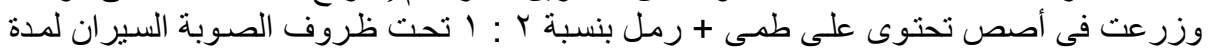

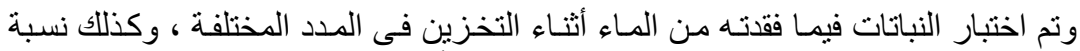

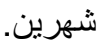

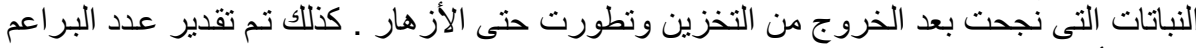

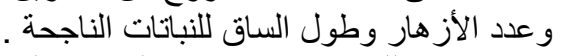
كذلك تم تقدير محتوى الشتلات المخزنة من الكربو هيدرات فى مر احل التخزين المختلفة وكانت أهم النتائج مايلى :

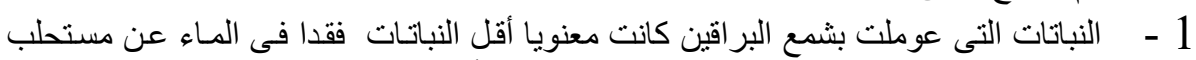

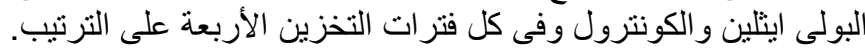

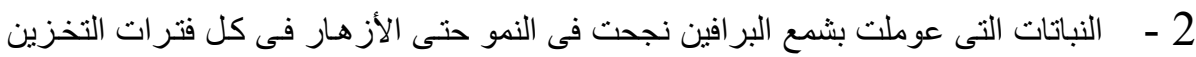

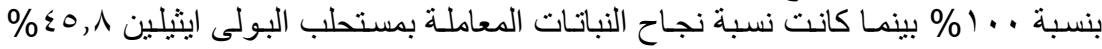

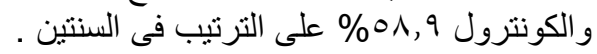

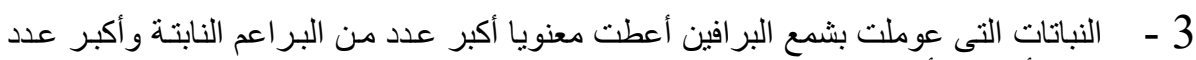

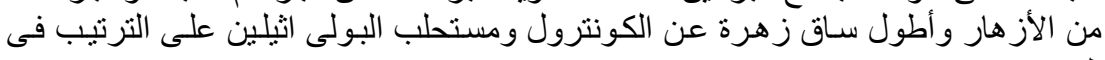
السنتين . الازهر

4

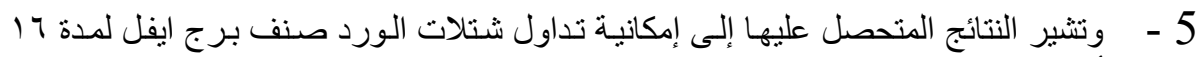

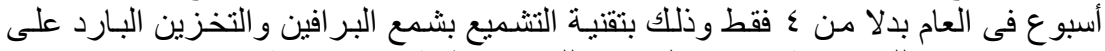
صفر مئوى وكذللك إمكانية تصدير الثتلات للخار جنظيفة وبدون نربة. 